\title{
Application of Geographic Information Systems for Characterization of Preharvest and Postharvest Factors of Squash (Cucurbita sp.) in Bolívar Department, Colombia
}

\author{
R.M. Marsiglia Fuentes' ${ }^{1}$ E. Torregroza Fuentes' 1 , S. E. Quintana ${ }^{2}$ and L. A. García - Zapateiro ${ }^{2 *}$ \\ 'Social Sciences and Education Faculty, Universidad de Cartagena, Cartagena-130015, Colombia; \\ rmarsigliaf@unicartagena.edu.co,etorregrozaf@unicartagena.edu.co \\ ${ }^{2}$ Department of Unit Operations, Food engineering. Universidad de Cartagena, Colombia; \\ Igarciaz@unicartagena.edu.co,squintanam@unicartagena.edu.co
}

\begin{abstract}
Objectives: To characterize the conditions of handling and productive potential of crops of squash (Cucurbita sp.) at Bolívar's department in terms of geo-referencing and growing areas. Methods: Statistics of sowing, harvesting, and production of the Bolívar Department, Colombia were compiled. Interviews, surveys, and field diaries were conducted considering strategic points of the producer's guild through use of the global positioning system (GPS). Finally, geo referenced maps of potential squash production areas were made using Quantum geographic information system code software (QGIS 2.0.1). Findings: Production of squash (Cucurbita sp.) is of great incidence and importance in the Bolívar Department, where this vegetable presents an essential product for inhabitants' food safety. This work included several tours through the production areas of the study region, where many surveys and interviews with producers and marketers enabled researchers to estimate the characteristics of the production chain of squash. The results show that increased production and areas favorable for the cultivation of squash are close to the banks of the Magdalena River and Canal del Dique. There the low-height squash crops are closer to rivers and water bodies, the yield per hectare is higher, and crops are planted up to twice a year. On the other hand, in upland areas, most of the time crops are planted only once a year as growth is influenced by the rainy season. Application: The results are useful for the groindustry sector because they enable us to locate the areas with the greatest potential for squash cultivation, preharvest, and postharvest needs.
\end{abstract}

Keywords: Cartographies, Crops, Farmers, Geo-Referencing, Squash, Vegetable Growing

\section{Introduction}

A Geographic Information System (GIS) is a collection of various tools and practices that work together to analyze spatial data. Its use has been increasing the recognition and identification of potential areas to produce crops of interest to improve food safety. Use of GIS has had a remarkable effect in the field of plant exploration owing to its capabilities of organizing and analyzing individual layers of spatial data and of providing tools to analyze and model the interrelationships among various spatial data layers. It is used to provide support for a wide variety of decisions based on data that are in the form of maps, images, reports, and field observations. It is a spatial tool that integrates hardware, software, data, methods, and people. A full range of the functional capabilities of a GIS includes data capture, input, manipulation, transformation, visualization, combination, query, analysis, prediction, modeling, and map output with respect to all types of geographically referenced data ${ }^{1}$. The tech-

${ }^{*}$ Author for correspondence 
nological developments endorsed by the management of information through specialized software have great application in the valuation of diverse areas ${ }^{2}$ among these applications are cultivation for food production due to the development of maps that acknowledge that the characteristics of a region constitute a "media" that helps businessmen and citizens make decisions and manage risk events. To evaluate the sustainability of economic growth and welfare, it is crucial to have a deeper understanding of how regional economic development affects the vulnerability of local communities and propensity to be adversely affected by the weather ${ }^{3}$.

Squash, which is the fruit of different species of the genus Cucurbita, is cultivated worldwide for its pulp and seeds for human nutrition. It has a high potential as an agricultural alternative due to its great versatility of use in food, medicine, and the agro-industry. It has always been a part of the diet of several regions of America, Asia, and Europe, and is raw material for the agro-industry of flour, starches, and concentrates for multiple uses in industry and in human and animal consumption. Its taxonomy and common names are of great importance as a crop with agro-industry potential ${ }^{4-6}$. It can be consumed directly, processed into soups, creams, sweets, purees, juices, pastry, and compotes; or added to dishes and beverages. It also can be used indirectly as raw material for the agro-industry (in flour and dehydrated) ${ }^{z}$. All these aspects show the squash is a product of significant impact in the food security of any region of the planet where its cultivation is propitiated. The principal physiological characteristic of squash is its oblong shape, widened in the distal proximity. Its crops have a thick pivoting root that can penetrate up to $1.80 \mathrm{~m}$ deep at maturity, although ramifications below the $0.60 \mathrm{~m}$ level are not important. In addition, it develops adventitious or nodal roots that reach lengths of $1.20-1.50 \mathrm{~m}$ with innumerable ramifications that increase the radical system ${ }^{\circ}$. The leaves of Cucurbita sp. are lobulated, but their outline is more orbicular than in C. pepo. The consistency of the leaves is variable, being a little hard in C. pepo and less in the other species ${ }^{2}$ having little marked leaf lobes and an apical lobe tip. The white spots at the junction of the ribs of the sheets are due to the presence of a thin layer of air below the epidermis. The fruit is characterized by having a hard and cylindrical peduncle, with a very wide diameter by hard cork. The seeds are white-off-white, with a darker margin than the center, uneven grooves on the surface, and a truncated straight apex ${ }^{10}$.
The archaeological records for the Cucurbita mos chat a type occur in southern Mexico, Guatemala, and Panama in Central America and extend to Colombia and Venezuela, presenting a profusion of varieties widely distributed in this region. Vestiges with similar dates, however, also are recognized in northern Belize and Tikal, Guatemala (2000 BC-850 AC) and Huaca Prieta, Peru (3000 BC). Due to this and the great morphological variation of the species, it has been difficult to accurately determine the center of its origin, although the north of Colombia recently has been proposed as the center because of the existence of local breeds that present an important morphological diversity. These regions, however, have not been fully explored for ratifying this fact; what can be confirmed is that it is a species domesticated in Latin America ${ }^{\underline{11}}$. The production chain of squash as well as other agricultural products becomes a food system, comprising a set of activities and results ranging from direct field production to consumption, which implies an interrelationship between the human and environmental dimensions ${ }^{12}$. Specifically, food systems are composed of four fundamental links: agricultural production activities, processing of raw materials and packaging, distribution and retailing of food, and consumption. Activities in food systems are carried out through interactions between the bio-geophysical and human $f$ rames of such systems. In this sense, characteristics of both frames can be stored in databases which, through information technology and the use of specialized software, allows for their analysis and subsequent decision making. The set of technologies, elements, and techniques that serve to guarantee the sustainable development of agriculture in general are linked to agricultural engineering systems. Among these we can find production machinery and agricultural collection, conventional sources and alternative energy, irrigation systems, land plowing, seeding, and preparation and/or adaptation of seeds corresponding to the main pre-harvest systems ${ }^{\frac{13}{3}}$. The principal aim of this paper is to determine the growing areas of squash in the Bolívar Department (Colombia), using GIS techniques to contribute to geographical and scientific debates on the mapping of suitable squash cultivation regions. Furthermore, this study has policy implications as it identifies regions and districts prone to optimum production and provides policymakers, decision-makers, and growers to feed into a more targeted climate adaptation. 


\section{Material and Methods}

\subsection{Cartographic Maps}

The mapping procedures were aimed at obtaining maps of squash-producing areas, and the reference material used was the one at the base in the SIGOT (IGAC) line, the Environmental Corporation, and the cartographic files. The cartographic information processing was carried out using the open source software QGIS version 2.12. Raster images with topographic and digital elevation information were obtained through ASTER Global Digital Elevation Model (ASTER GDEM). The Coordinate Reference System (SRC) used in the management of all layers, regardless of the raster or vector condition, was MAGNA - SIRGAS (National Geocentric Reference Frame), considering Resolution No. 068 of January 28, 2005, by which the MAGNA-SIRGAS was adopted as the only official datum of Colombia.

\subsection{Delimitation of the Study Area}

The study area corresponded to traditional vegetablegrowing areas in the Bolívar Department. It is important to consider that the production of squash is linked to areas near the abundant bodies of water in the central and southern municipality of the department such as Magangué, Mompox, Barranco de Loba, Hatillo de Loba, and Altos del Rosario. These areas, as well as municipalities of the north of the department - Turbaco, Arjona, Santa Rosa, Soplaviento, Villanueva and Santa Catalina - were visited and tours were made for information collection.

\subsection{Instrument to Recollect INFORMATION}

In addition to the cartographic developments, interviews and surveys were carried out during fieldwork aimed at obtaining information from key actors linked to the process of cultivation, transportation, and marketing of squash. These were important aspects of achieving an informed approach regarding this vegetable as a food system. The survey, interview, and field diary instruments were designed to obtain data on the productive potential of squash cultivation in the study area. Work in the territory was considered using the economic and social Development Zones (ZODES), which constitute areas of economic and social planning of the department established within the departmental development plan of Bolívar 2001-2003 "social consensus for coexistence." The ZODES concept is the grouping and strategic integration of municipalities, considering characteristics that enable the implementation of specific investment projects and programs. For the present case, the department is divided into six ZODES: Dique, Montes de Maria, Depresion Momposina, Loba, Mojana, and Magdalena Medio $\underline{14}$.

\section{Results and Discussion}

\subsection{Squash Characterization in the Bolívar Department}

Figure 1 shows the classification of municipalities in the Bolívar Department by ZODES Dique, Montes de Maria, Mojana, Depression Momposina, Mojana, Magdalena Medio and Loba while Table 1 provides characterization of the squash crop according to this information and the statistics reported by the Ministry of Agriculture and Rural Development (MADR) about the records of harvested area, area planted, and yield of crops from 2007 to 2013 .

\section{BOLIVAR DEPARTMENT} Economic and Social Development Zones
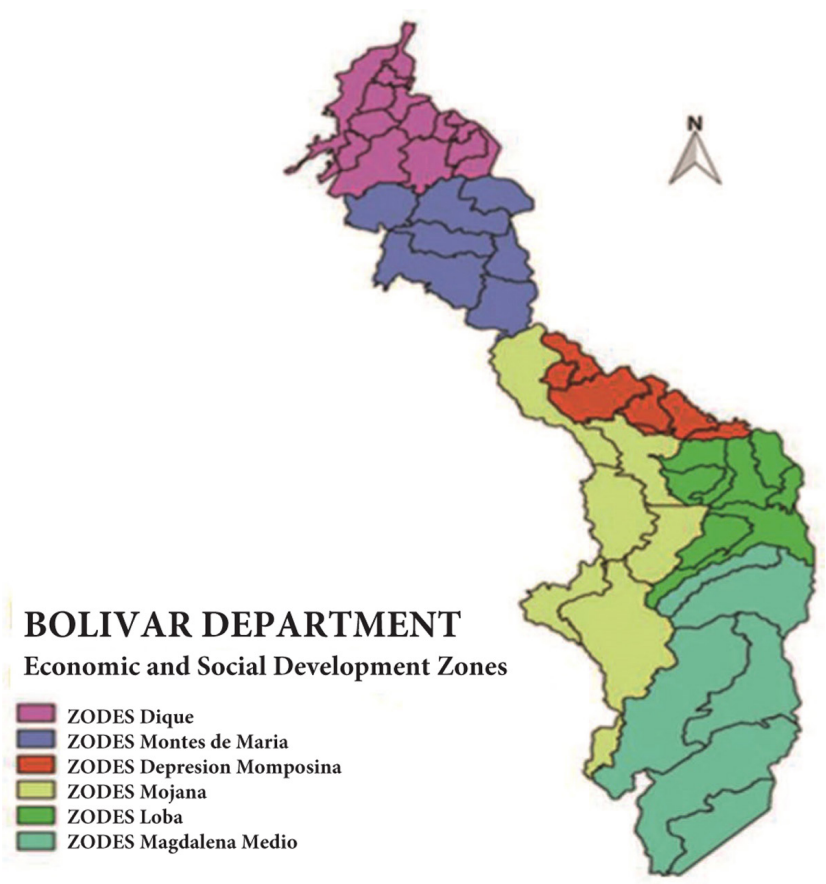

Figure 1. Department of Bolivar distributed in Economic and Social Development Zones. 
Table 1. Classification of the municipalities of the Bolívar department by ZODES

\begin{tabular}{|c|c|c|}
\hline ZODES & MUNICIPALITIES & AGRICULTURAL CHARACTERIZATION \\
\hline Dique & $\begin{array}{l}\text { Cartagena de Indias, Turbaco, Arjona, Calamar, Arroyo } \\
\text { Hondo, Clemencia, Mahates, San Cristóbal, San Estanislao } \\
\text { de Kostka, Santa Catalina, Santa Rosa de Lima, Turbana, } \\
\text { Soplaviento y Villanueva }\end{array}$ & $\begin{array}{l}\text { Agricultural pantry of Cartagena and } \\
\text { Barranquilla, industrial, port and tourist } \\
\text { center located in Cartagena. The main crops } \\
\text { are maize, cassava, banana, African palm and } \\
\text { mango }\end{array}$ \\
\hline $\begin{array}{l}\text { Montes de } \\
\text { María }\end{array}$ & $\begin{array}{l}\text { Carmen de Bolívar, San Juan Nepomuceno, San Jacinto, } \\
\text { María La Baja, Córdoba, Zambrano y El Guamo, }\end{array}$ & $\begin{array}{l}\text { With a mining and agricultural vocation, } \\
\text { characterized by crops of white and yellow } \\
\text { corn, cassava, yams, palm oil wood and } \\
\text { avocado }\end{array}$ \\
\hline Mojana & $\begin{array}{l}\text { Magangué, Pinillos, Tiquisio, Achí, Montecristo y San } \\
\text { Jacinto del Cauca. }\end{array}$ & $\begin{array}{l}\text { It has natural resources and biodiversity, with } \\
\text { a mining and agricultural vocation. Rice and } \\
\text { corn. are the main agricultural products. }\end{array}$ \\
\hline $\begin{array}{l}\text { Depresión } \\
\text { Momposina }\end{array}$ & $\begin{array}{l}\text { Cicuco, Talaigua Nuevo, Mompox, San Fernando y } \\
\text { Margarita }\end{array}$ & $\begin{array}{l}\text { Its vocation is cattle and crafts. Highlights } \\
\text { include goldsmiths and cabinet makers. } \\
\text { Presence of Orange crops }\end{array}$ \\
\hline Loba & $\begin{array}{l}\text { Altos del Rosario, Barranco de Loba, San Martín de Loba, } \\
\text { El Peñón, Hatillo de Loba, Regidor, Río Viejo y Norosí }\end{array}$ & $\begin{array}{l}\text { With agricultural and mining vocation, its } \\
\text { main crops are corn, rice, cassava and palm. }\end{array}$ \\
\hline $\begin{array}{l}\text { Magdalena } \\
\text { Medio }\end{array}$ & $\begin{array}{l}\text { Arenal, Cantagallo, Morales, San Pablo, Santa Rosa del Sur } \\
\text { y Simití }\end{array}$ & $\begin{array}{l}\text { Its agricultural and mining vocation. Its main } \\
\text { crops are maize, cassava, oil palm and cocoa. }\end{array}$ \\
\hline
\end{tabular}

Source: (BOLIVAR GOVERNMENT Development Plan, 2001 - 2003)

\subsubsection{Loba ZODES}

The statistics of crop production in Altos del Rosario, Barranco de Loba, San Martín de Loba, and El Peñón municipalities are shown in Figure 2. The sowing, harvesting, and production of squash increased in all municipalities except in El Peñon, which showed some differences from an average production for this vegetable. From 2009 to 2010, there was a decrease in production in the municipalities of Altos del Rosario and Barranco de Lobarelated with the winter waves and the El Niño and La Niña weather phenomena.

For 2013, Altos del Rosario recorded a total of 45ha of planted area and 40 ha of harvested area, with an approximate production of 600 tons. In Barranco de Loba, however, statistics were not recorded in 2013, which by 2012 had a planted and harvested area of 40 ha with a production of 400 tons of squash. San Martin de Loba had the highest production of squash in 2008, with about 250 tons and a sown and harvested area of $25 \mathrm{ha}$. It is important to note El Peñón in 2007 had a planted area of 100 ha and a harvested area of 40 ha with a production of 278 tons. By 2013, however, it only had 15 ha of planted and harvested area with a production of 150 tons, a decrease of $85 \%$.

\subsubsection{Depressión Momposina ZODES}

The statistics of municipalities of the Depression Momposina ZODES report the harvested area and production of squash in Hatillo de Loba and Mompox (Figure 3). In 2007, the sowing and harvesting area in Hatillo de Loba was 80 ha and 20 ha, respectively. There was a significant increase in 2012 with a record of 120 ha of planted and harvested area and a significant production of 1,800 tons. In 2013, a significant decrease was observed, however, when 30 ha were registered as planted and harvested areas with 360 tons produced. For Mompox, a considerable increase was observed in 2011 and in 2013, it showed a planted area of 35 ha from which 30 ha were harvested with a production of 450 tons of squash. 

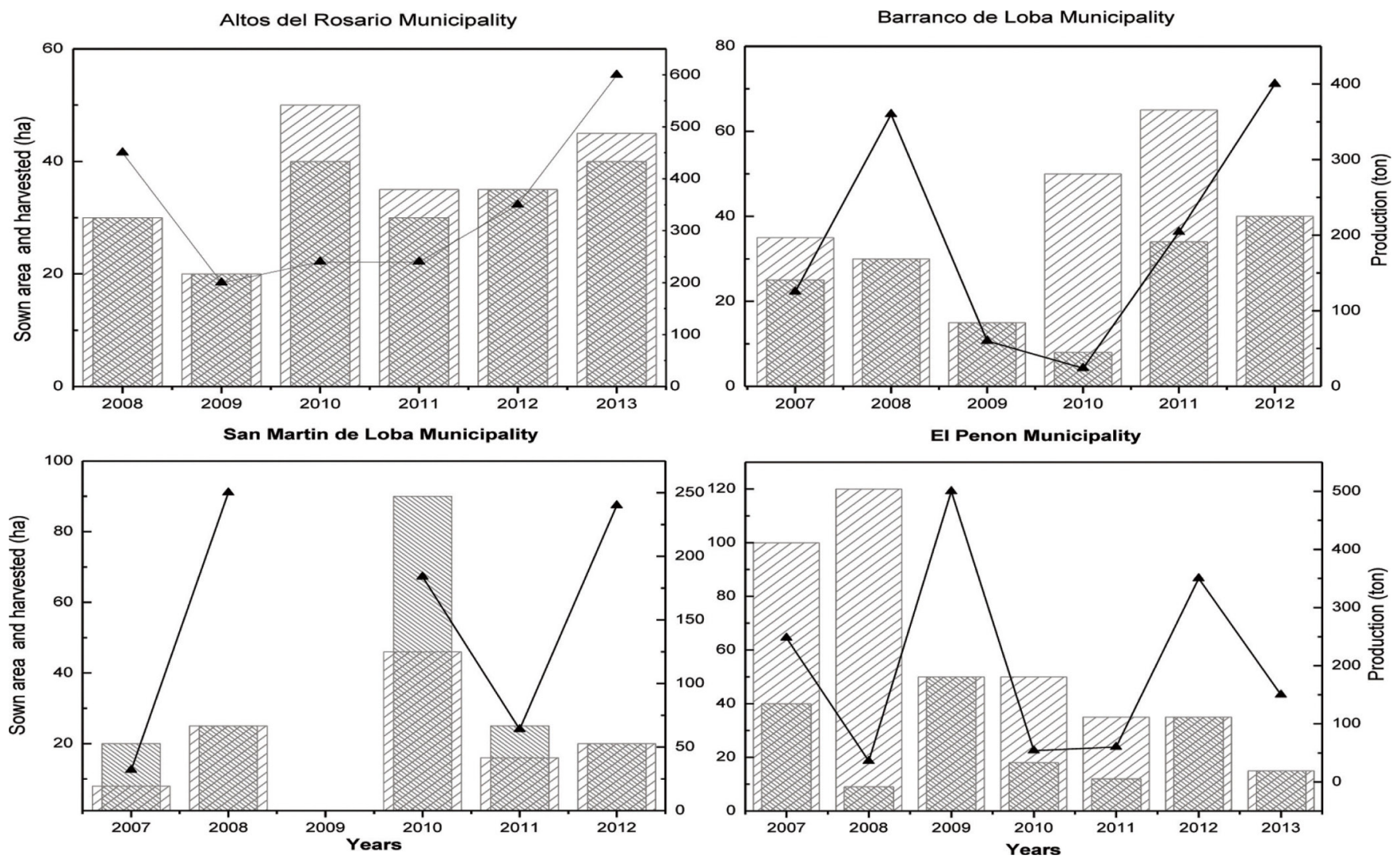

Figure 2. Statistics of harvested area sown area and production —— of pumpkin in the Loba ZODES, from 2007 to 2013.
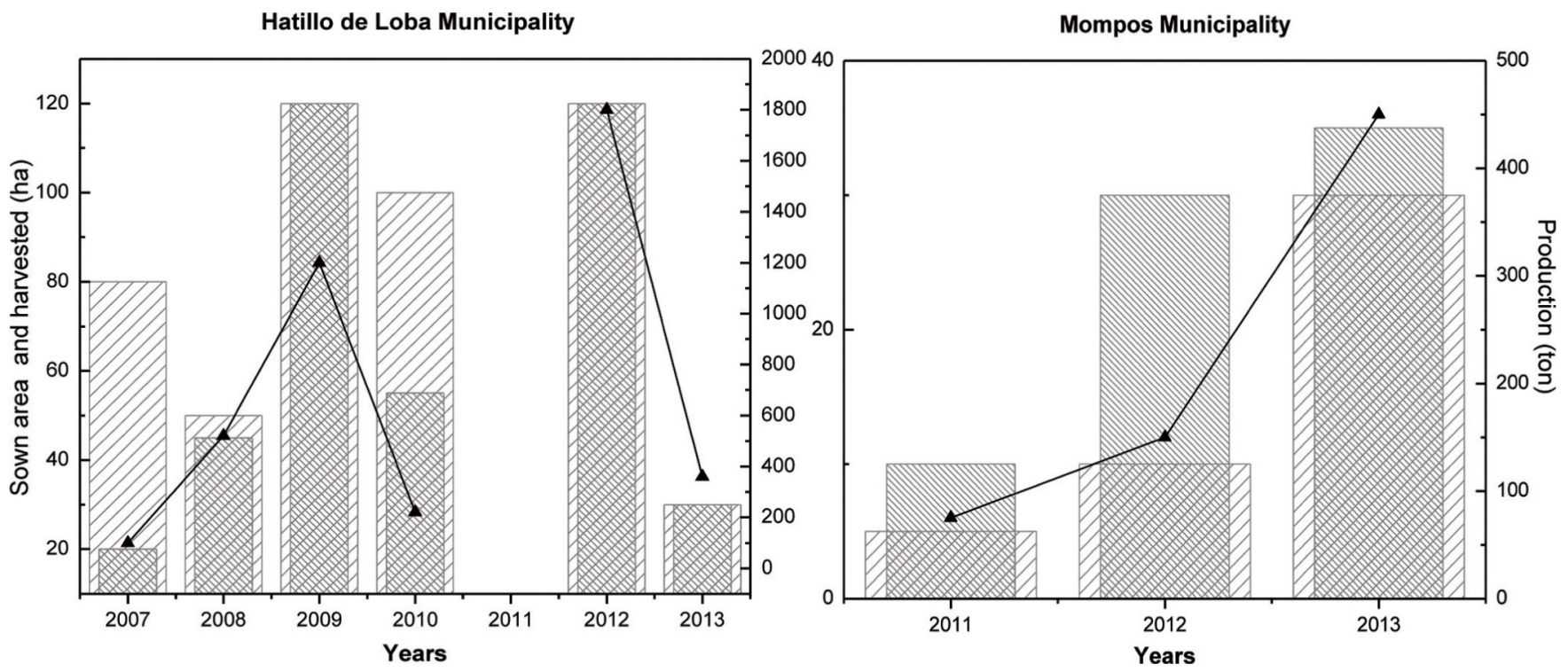

Figure 3. Statistics of harvested area sown area $\mathrm{k}$ and production —ـ of pumpkin in the Depresión Momposina ZODES, from 2007 to 2013 . 


\subsubsection{Mojana ZODES}

Mojana ZODES only reported statistics of the municipality of Magangué (Figure 4), which showed a significant increase in production of squash for 2012 with a planted area of 120 ha, all of which was harvested. In 2013, however, the area sown decreased and production was down to less than half compared to the previous year.

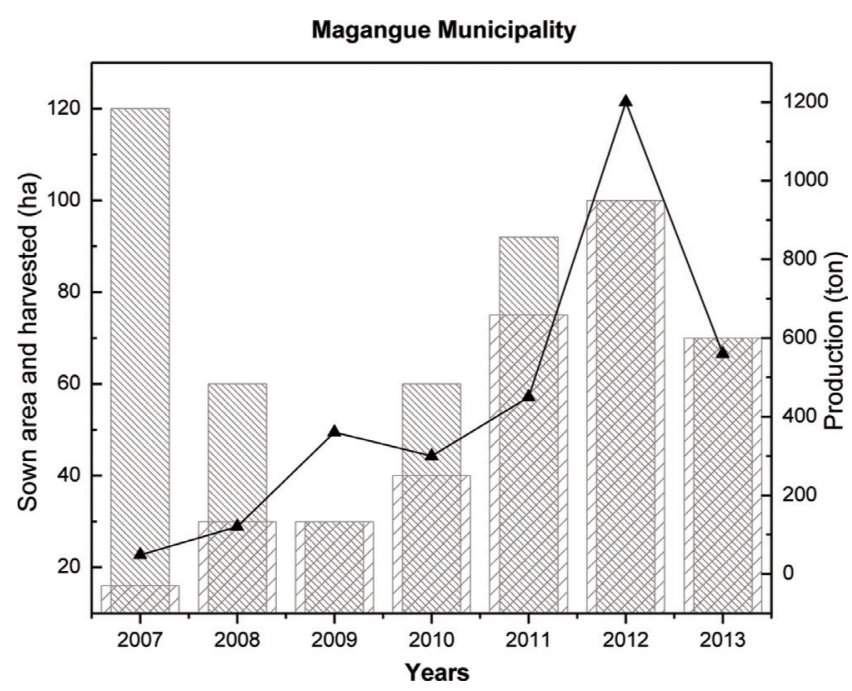

Figure 4. Statistics of harvested area sown area $\mathrm{W}$ and production —— of pumpkin in the Mojana ZODES, from 2007 to 2013.

\subsubsection{Dique ZODES}

For the Dique ZODES, the only municipality that reported squash statistics was Santa Catalina (Figure 5). It only had records since 2012 and only had 3 ha of planted area that could be entirety harvested. By 2013, the area planted doubled with a production of 60 tons, which almost tripled the production of the previous year.

In the statistics obtained for the Bolívar Department, the production was not defined by the sown area, the data for which varies considerably from year to year. This serves as a basis for the identification of municipalities with potential in squash production, however, and promotes the agricultural chain as an alternative to the development of new products in other municipalities that have optimal conditions for planting and conditioning this product.

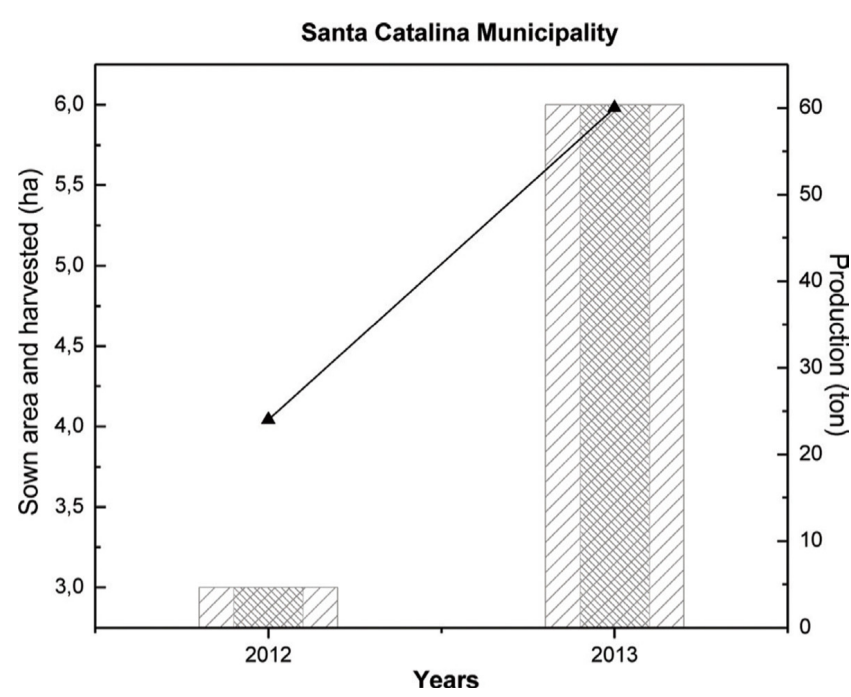

Figure 5. Statistics of harvested area sown area $\mathrm{X}$ and production - of pumpkin in the Dique ZODES, from 2012 to 2013.

\subsubsection{Montes de María ZODES}

The municipalities of Montes de María ZODES did, not present statistics related on squash production, its grow it for own consumption and not for commercial purposes, due to their higher production has been related with products such as avocado, cassava, yams, bananas, rice, and tobacco. However, it is recognized as one of the best lands for sowing in Colombia because of its different altitudes, which allows a wide range of agricultural products.

\subsection{Application of Data Collection and Geo Referencing Tools}

The surveys and interviews with farmers in the study area showed similar practices of pre- and post-harvest management of the squash crop in all the municipalities that report squash production. The level of technology use is low or null, with the knife and scythe being the main tools used. The ease of propagation of the seed of this vegetable makes it a crop of few requirements $\frac{15}{15}$ to prepare the seed, a mechanism is needed to break the rigid shell that it presents. Because squash is a cultivated plant, in most cases man is the one who disperses the seed to other environments, while in other times, within the same crop, the shell can be accidentally broken, releasing the seeds "in situ." The latter method is related to the way farmers in the Bolívar Department sow the squash seeds. 
The seeds are planted in lands without any previous preparation. After deforestation and the burning of vegetation, when the rains are expected to begin, it is time to do the sowing. Squash is usually cultivated along with other products such as cassava, corn, chili, beans (multipurpose). The seeds are placed three meters apart in length and width to facilitate the planting of the crop and its correct distribution by the land. This information coincides with the study reported by in ${ }^{10}$. Sowing of the seeds typically occurs in November, for the winter season, and in June, which is done when the river level is lower, enabling farmers to take advantage of the nutrients left in the soil. Squash usually is usually ready for harvest in three months, and the crop can be harvested twice a year. Tractors, motorcycles, and animals are used to transport harvested products to distribution centers and markets. From there trucks and boats are used in the municipalities of the center and south of Bolívar; these go by the Dique canal until arriving at the municipalities in the north.
As can be seen in the geo referenced map (Figure 6), in Barranco de Loba and Altos del Rosario, the number of planted hectares is low compared to the total area available and the productivity potential, mainly because there are no collection centers. The nearest collection center is in El Banco Magdalena municipality and river transport from the plots is usually more expensive than farmers are willing to pay.

The Hatillo de Loba municipality has an advantage because of its location closest to a collection center. Most of the squash received at the collection center in El Banco Magdalena comes from this municipality. The other municipalities that report production of squash in the south of Bolívar use it mainly for self-consumption; this possibly is due to the difficult access and distribution routes that farmers must use to transport and sell their products to the outskirts of the municipalities or take them to the collection centers.

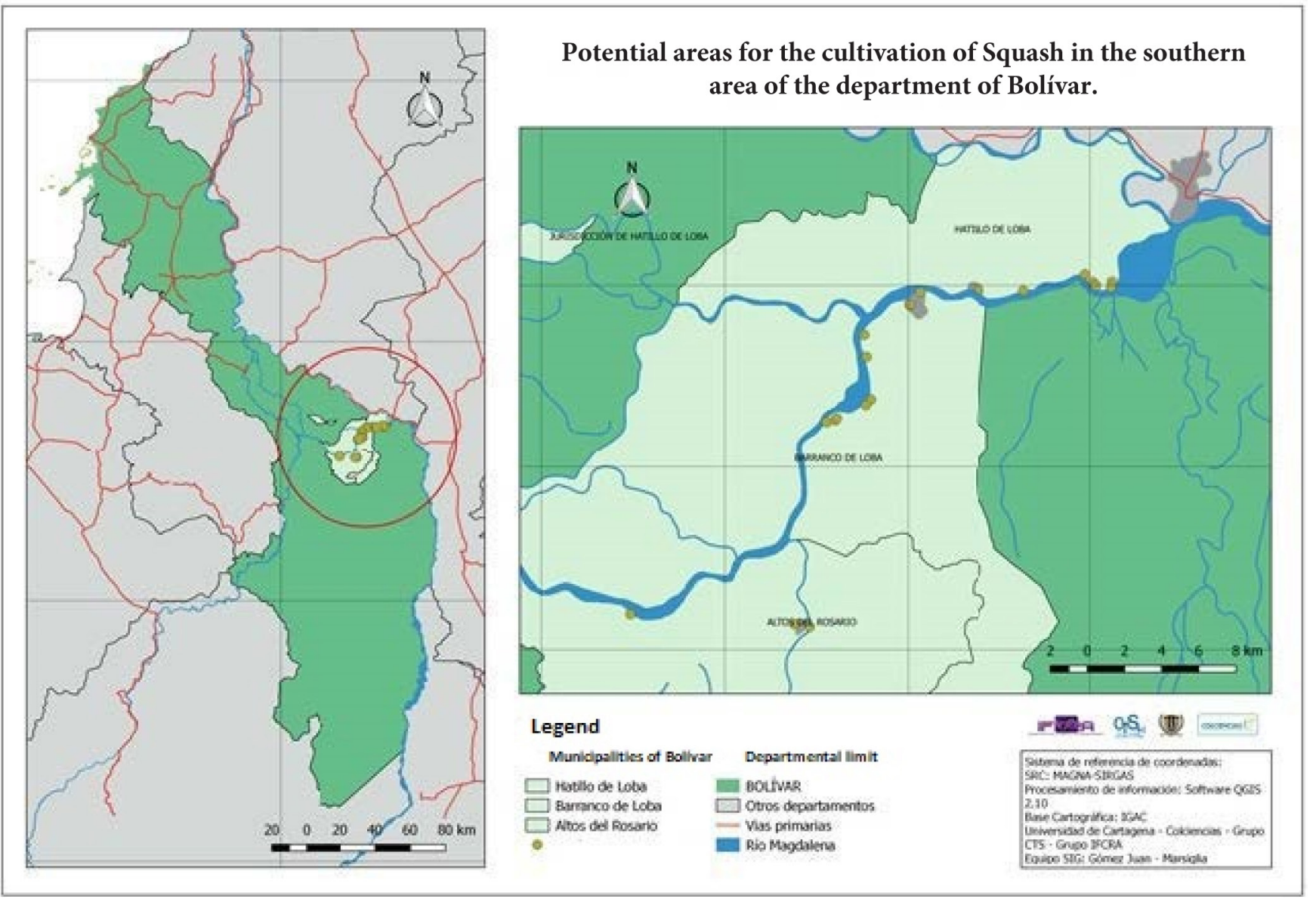

Figure 6. Geo-referenced map of the municipalities that report squash cultivation in the south of the Bolívar department. 
The geo referenced points between the municipalities of Magangué and Mompós, which are near the Magdalena River (Figure 7), are potential areas for squash cultivation in the central zone of the Bolívar Department. In relation to the statistics (Figures $2 \& 3$ ), the municipality with the highest production is Magangué, but comparing the results from the surveys and interviews of farmers, traders, and transporters, the largest producer in this area is the municipality of Mompós. This is due in large part to the fact that most of the harvested production is transported to Magangué because it is a central trading port, from there it is distributed by the Magdalena River and by land to the north of the department to cities such as Cartagena, Barranquilla, and Santa Marta.

In the northern part of the Bolívar department there are potential areas for squash cultivation (Figure 8), but today most farmers only grow squash for self-consumption (manager). In municipalities such as Turbaco,
Turbana, and Arjona, production is practically nil because most of the farmers come to the Cartagena market to look for products from the south of the department. The municipalities that have the best conditions for planting squash in this area are Clemencia, Santa Catalina, Santa Rosa, and Soplaviento, which are at a lower height and near watersheds that favor cultivation.

For purposes of discussion and considering the georeferencing of potential growing areas in the Bolívar Department, it is evident that the increased production and rich areas for growing squash are on the banks of the Magdalena River and the Dique canal. Considering the statistics (Figures 2, 3, 4, and 5) comparing them with the maps, it follows that the closer the squash crops are to rivers and basins, the higher will be the yield per hectare planted. There is a direct relation of the culture with the availability of water bodies around it which also offers great possibilities of transformation and technological

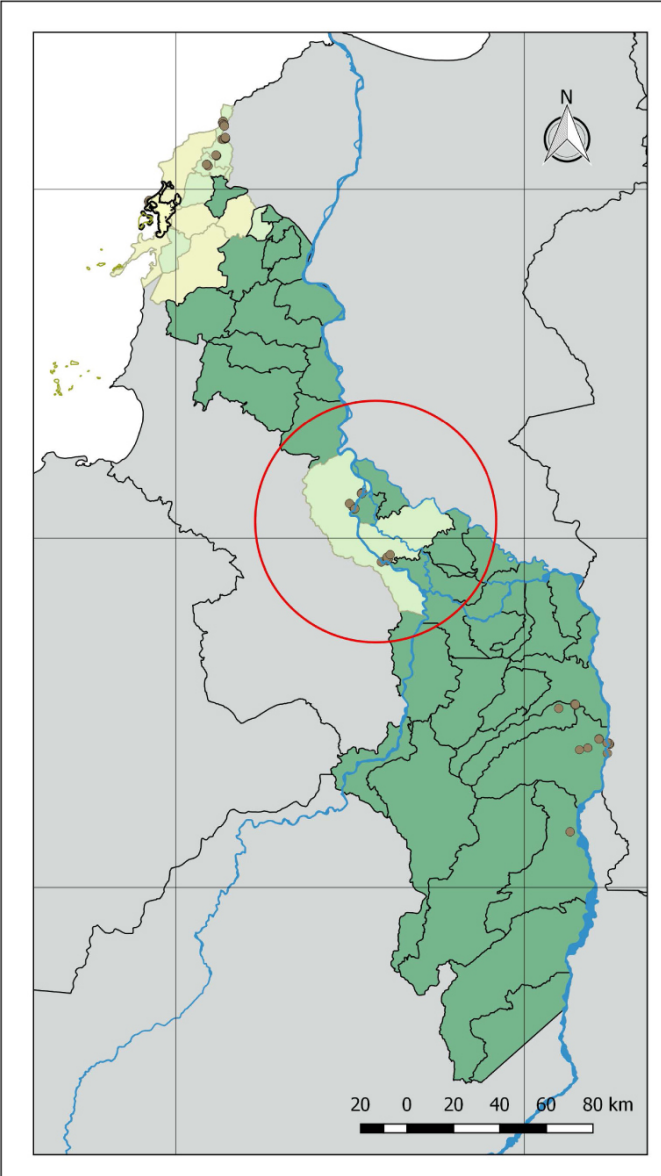

\section{Potential areas for the cultivation of squash in the central area of the department of Bolívar.}

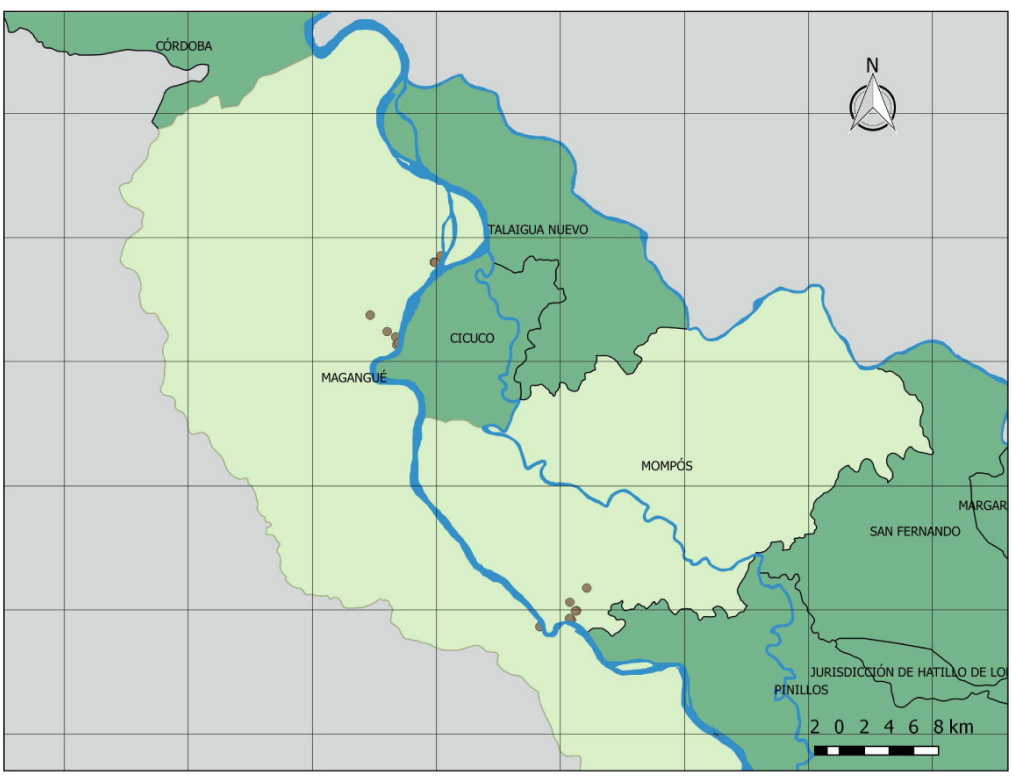

Legend

Municipalities of Bolívar

$\square$ Visited municipalities with high potential.

Visited municipalities with low potential.

Other municipalities.
- Georeferenced points

- Primary routes

Departmental limit

Magdalena river

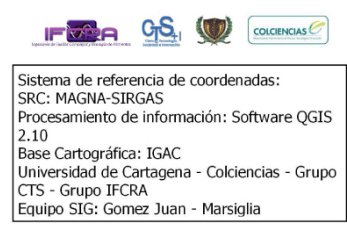

Figure 7. Georeferenced map of the potential Squash cultivation zones in Magangue and Mompós. 


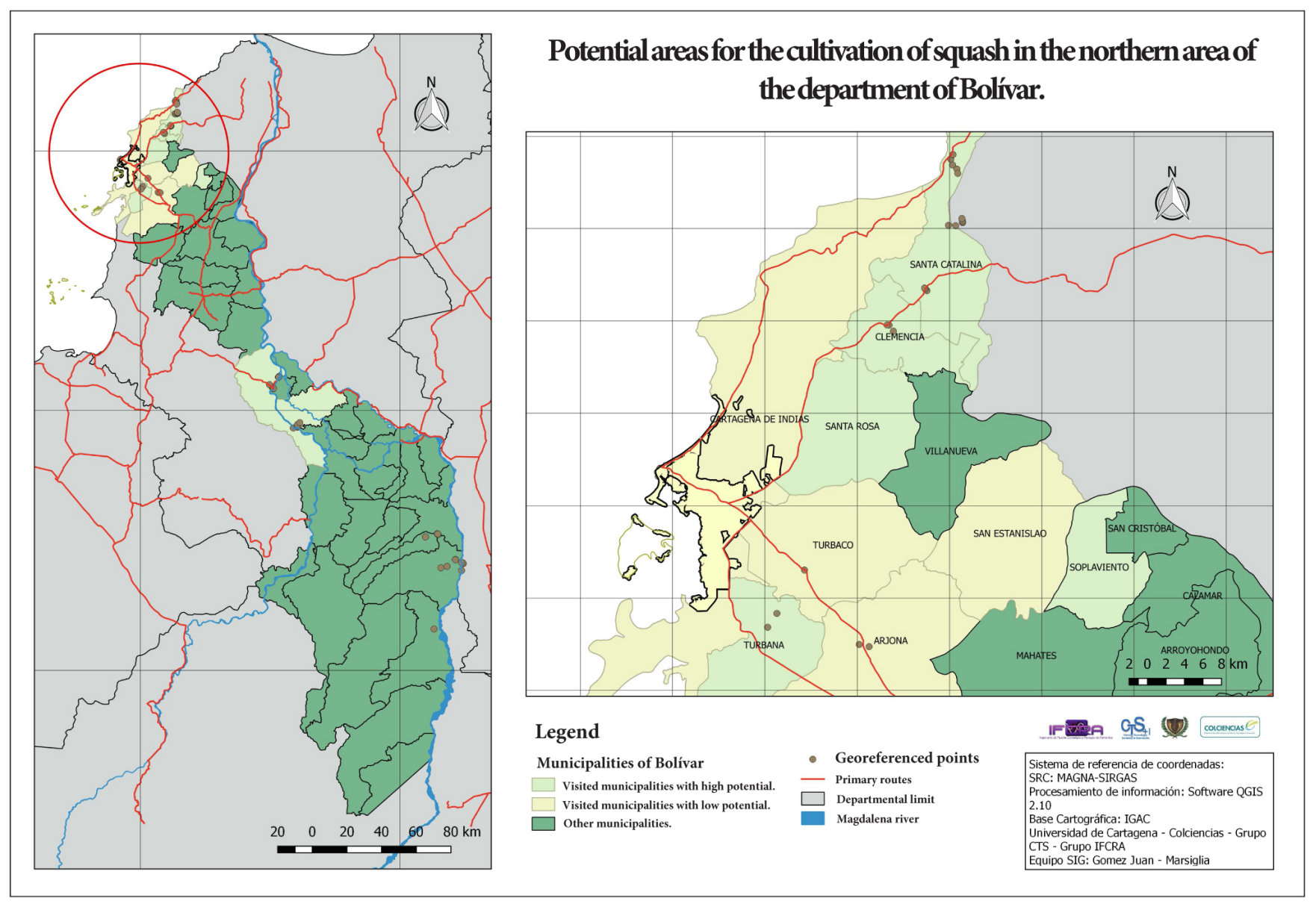

Figure 8. Geo-referenced map of the potential zones for squash cultivation in the north of the Bolívar department.

development of squash to provide the population with sustainable economic and social growth that through value-added products $\frac{16,17}{}$.

\section{Conclusion}

The characterization of aspects related to postharvest management conditions, obtained through direct dialogue with farmers and the application of surveys, provided valuable information about the cultivation of squash in the rural areas of the Bolívar Department and the gathering of data concerning the difficulties presented by small and medium producers. Likewise, the use of GIS made it possible to obtain cartographies with basic information that show the points and potential areas of squash cultivation within the zones of the department of Bolívar.
The characterization of the basic pre- and post-harvest conditions of the pumpkin find in the use of GIS a real possibility for the decision making and analysis of the potentialities of this type of vegetable to advance initiatives aimed at strengthening regional food security.

\section{Acknowledgement}

This work is part of a research project "Basic and applied research projects in the agricultural sector (667 of 2014); Project 0487-2014 code 1107-667-44997" sponsored by the Administrative Department of Science, Technology, and Innovation (CTeI) - Colciencias (Colombia). The authors are grateful for their financial support. 


\section{References}

1. Campbell J, Shin M. Essentials of Geographic Information Systems. Flat World Knowledge; 2011. p. 1-177.

2. Martínez P, Rojas I, Valdés SL, Noa RR. Vulnerabilidad espacial al dengue: Una aplicación de los sistemas de información geográfica en el municipio Playa de Ciudad de La Habana. Revista cubana de salud pública. 2003; 29(4):1-2.

3. Christopher FB. Managing the risks of extreme events and disasters to advance climate change adaptation: special report of the intergovernmental panel on climate change. Cambridge University Press; 2012. p. 1-594.

4. Saade RL. Estudios taxonómicos ecogeograficos de las Cucurbitaceae Latinoamericanas de importancia económica. International Plant Genetic Resources Institute: Mexico; 1995. p. 1-281.

5. Robinson RW. Cucurbits RW Robinson DS Decker Walters. Crop production science. England; 1997.

6. Loy JB. Morphophysiological aspects of productivity and quality in squash and squashs (Cucurbita spp.). Critical Reviews in Plant Sciences. 2004; 23(4):337-63. Crossref.

7. Menjivar-Flores JC, Murillo CFE, Cordoba HEM. Evaluación de la eficiencia de tres fertilizantes edáficos sobre el rendimiento y calidad del zapallo (Cucurbita maxima var. Unapal- Mandarino). Universidad Nacional Abirta y a Distancia. 2015; 6(1):1-14.

8. MacAdam JW. Structure and function of plants. John Wiley \& Sons: USA; 2011. PMCid:PMC3111885

9. Whitaker TW, Davis GN. Cucurbits Botany Cultivation and Utilization. Leonard Hill (Books) Ltd; 1962.
10. Gaspera D, Elisei RA, Ayastuy VR, Khier ME, Miglierina M, Delhey AM. Manual del cultivo del zapallo anquito (Cucurbita moschata Duch). Instituto Nacional de Tecnología Agropecuaria Ministerio de Agricultura Ganadería y Pesca de la Nación. Publicaciones Regionales: Argentina; 2013. PMCid:PMC3861122

11. Bisognin DA. Origin and evolution of cultivated cucurbits. Ciencia Rural. 2002; 32(4):715-23. Crossref.

12. Gómez-Juan A, Cantillo M, Torregroza E, Borja-Barrera F. Gestión Ambiental y Sistemas Alimentarios: Una Nueva Dimensión Transdisciplinar. Revista Ciencias e Ingeniería al Día - Universidad de Cartagena. 2010; 5(1):67-82.

13. Delisles PD, Quan CAL. Uso de las imágenes de satélites y los SIG en el campo de la Ingeniería Agrícola. Revista Ciencias Técnicas Agropecuarias. 2013; 22(4):75-80.

14. Instituto Geográfico Agustín Codazzi (IGAC) [Internet]. [cited 2017 Aug 30]. Available from: http://www.igac.gov. co/wps/portal/igac/raiz/iniciohome/geografia.

15. Lira RS, Montes-Hernández S. Cucurbits (Cucurbita spp.) neglected crops: 1492 from a different perspective. FAO: Italy; 1992. PMCid:PMC364075

16. Ruiz RJL, Llanos AR, Albo RG. Posibilidades de transformación productiva y desarrollo tecnológico del caribe colombiano. Revista Economía Caribe; 2009. p. 1-40.

17. Cruz RO, Martín G, Vantour A, Páez M, Ponvert DR. Diagnóstico de áreas vulnerables a la desertificación empleando información satelital y SIG en un territorio de la república de Cuba. Luján. Revista SELPER; 2010. p. 32-41.PMid:19820407 